\title{
直視下内尿道切開術の検討
}

\begin{tabular}{|c|c|c|c|c|c|}
\hline 狩場 & 岳夫 & 豊嶋 & 穆 & 佐藤 & 英敏 \\
\hline 土田 & 均 & 江口 & 謙一 & 熊谷 & 乾二 \\
\hline 飯泉 & 達夫 & $\begin{array}{c}\text { 矢崎 } \\
\text { 松 }\end{array}$ & $\begin{array}{l}\text { 恒忠 } \\
\text { 矢院 }\end{array}$ & 和久 & 正 \\
\hline
\end{tabular}

\section{STUDIES OF THE OPTICAL INTERNAL URETHROTOMY}

\author{
Takeo Kariba, Atsushi Toyoshima, Hidetoshi Satoh, Hitoshi Tsuchida, \\ Kenichi Eguchi, Kenji Kumagai, Tatsuo lizumi, \\ Tsunetada Yazaki and Masayoshi Waku \\ Department of Urology, Teikyo University School of Medicine \\ (Director: Prof. Masayoshi Waku) \\ Kohtaro Matsuse \\ Matsuse Clinic
}

Results of optical internal urethrotomy (OIU) on 64 patients during the last 42 months were reviewed. The patients subjected were all male and OIU alone was done on 28 patients and OIU combined with either TUR-P or TUR-Bn on 36 patients. The former group ranged in age from 17 to 82 years old( mean 47.6). The stenotic sites were bulbomembranous region in 23 patients. pendulous region in 2 and both regions in 3. Etiology was traumatic or iatrogenic in 7 patients, postinflammatory in 11 and congenital in 10. 21 patients improved by OIU alone, 1 improved by metal sound dilatation following OIU and 2 with traumatic stenosis necessitated TUR following OIU and 4 remained in unfavorable condition. The latter group ranged in age from 44 to 88 years old (mean 65.9). The stenotic sites were bulbomembranous region in 27 patients and extensive (from membranous to pendulous) in 9. Etiologywas iatrogenic in 1 patient, postinflammatory in 29 and congenital in 6.26 patients improved by OIU alone and 9 patients necessitated metal sound dilatation. The remainder was not improved. In general neither postoperative deterioration nor intraoperative complications were encountered.

要旨：1982年12月から1986年 5 月をでの 3 年 6 カ月に当科で経験した直視下内尿道切開術症例64例につ いて臨床的検討を行った。

直視下内尿道切開術のみを行った症例は28例であった．年路令は17歳から82歳（平均：47.6歳）であっ た。狭窄部位は球膜様部が23例，振子部が 2 例で両方におよぶもの 3 例であった。狭窄の原因は外傷性 または医原性 7 例, 炎症性11例, 先天性10例であった. 21 例が術後特に処置を要せず改善し，1例が金 属ブジーによる尿道拡張術後改善した．6例は改善しなかったが，5ち 2 例は狭窄部を経尿道的に切除 した.

TUR-P または TUR-Bnを併せて行った症例は36例であった．年齢は44歳から88歳（平均：65.9歳） であった。狭窄部位は球膜様部が27例で 9 例が振子部から膜様部まで連続していた。原因は医原性 1 例, 炎症性29例，先天性 6 例であった．26例が術後特に処置を要せず改善し，9例が金属ブジーによる尿道 拡張術後に改善した。1 例のみ良好な結果が得られなかった。

直視下内尿道切開術は，適応を誤らなければ尿道狭窄に対する優れた治療法と思われた。術後合併症 も少なく，その安全性扣よび操作性から考劣て，今後尿道狭窄の治療の主流になるものと思われた。 


\section{緒言}

尿道狭窄に対する治療法は尿道ブジー，内尿道切開 術，尿道形成術に大別される. 内尿道切開術は古くか ら行なわれている方法であるが，操作が盲目的である といら欠点を有している. 近年内視鏡の発達に伴い, 直視下内尿道切開術が行なわれるようになり，良好な 成績が報告されるようになってきた。我々も直視下内 尿道切開術を施行し満足すべき結果を得たので報告す る.

\section{対象}

昭和 57 年 12 月より昭和 61 年 5 月までの 3 年 6 カ月間 に排尿困難を訴えて当科を受診した男性尿道狭窄64例 を対象とした，直視下内尿道切開術のみを行なった症 例は28例で, 経尿道的前立腺切除術 (以下 TUR-P と略 す）あるいは経尿道的膀胱䅡部切除術（以下 TUR-Bn

Table 1 Age distribution

\begin{tabular}{cc}
\hline Age & No. cases \\
\hline $10-19$ & $1(0)$ \\
$20-29$ & $4(0)$ \\
$30-39$ & $5(0)$ \\
$40-49$ & $8(4)$ \\
$50-59$ & $10(4)$ \\
$60-69$ & $18(13)$ \\
$70-79$ & $14(12)$ \\
$80-89$ & $4(3)$ \\
\hline Total & $64(36)$ \\
\hline
\end{tabular}

( ): Combined with TUR-P \&/or TUR-Bn

Table 2 Etiology

\begin{tabular}{c|c}
\hline Etiology & No. cases \\
\hline Traumatic & $5(0)$ \\
Iatrogenic & $3(1)$ \\
Inflammatory & $40(29)$ \\
Congenital & $16(6)$ \\
\hline Total & $64(36)$ \\
\hline
\end{tabular}

( ): Combined with TUR-P \&/or TUR-Bn

Table 3 Sites of urethral stenosis

\begin{tabular}{l|c}
\hline \multicolumn{1}{c|}{ Site } & No. cases \\
\hline Pendulous & $2(0)$ \\
Bulbomembranous & $50(27)$ \\
Both & $12(9)$ \\
\hline \multicolumn{1}{c|}{ Total } & $64(36)$ \\
\hline
\end{tabular}

( ) : Combined with TUR-P \&/or TUR-Bn
と略す)を併せて行なった症例は36例であった。年齢, 原因，狭窄部位は Table 1〜3に示した。

\section{器具および操作}

直視下内尿道切開術にはオリンパス社製 OES ウレ スロトーム（cold knife）を用いた。光源・潅流装置等 は通常の TUR と同様のものを用いた。

手術は 1 例（局所麻酔）を除き，全例硬膜外麻酔下 に截石位で行なった。尿道鏡にて尿道狭窄を確認した。 狭窄部の切開に際しては TUR と同様に切開刀を前後 に操作し，12時の方向を切開した。多くの症例では 12 時方向のみの切開で狭窄は改除されたが，狭窄部の症 痕が高度な場合には適宜 3 時, 9 時の方向にも切開を 追加した。さらに狭窄が高度な場合には，4末たは5 Fr.の尿管カテーテルを插入し，これをガイドとして 切開を行なった。

術後は止血および創部の再癒合防止のために $22 \sim 26$ Fr. のバルーンカテーテルを留置した。 留置期間は原 則的に $5 \sim 7$ 日間とした. 外尿道口は充分消毒後, ガー ゼで被覆した。化学療法は一定の基準を設けず適宜使 用した。

\section{結 果}

治療成績の判定は術後 $2 \sim 4$ 週目の自覚症状および 尿道造影, 金属ブジー, 尿流量測定を行い, Walther ら の判定基準を参考にして行なった（Table 4).

直視下内尿道切開術のみを行なった28例では，21例 が術後とくに処置を要さず改善，1例は金属ブジーに よる尿道拡張術後に改善, 他の 6 例は良好な結果が得 られなかった。このらち 2 例は外傷性尿道狭窄の症例 で盤痕部を切除し改善した。 TUR-Pまたは TUR-Bn を併せて行なった36例では，26例が術後とくに処置を 要せず改善，9例は金属ブジーによる尿道拡張術後改 善した。1例のみ改善が得られなかった。

改善が得られなかった 5 例のうち 1 例は，外傷性尿 道狭窄の症例で, 術後カテーテル留置は可能であった が,骨盤骨折による尿道偏位のため排尿状態は不良で, 膀胱瘦による管理を余儀なくされている。他の 4 例は

Table 4 Postoperative results

\begin{tabular}{l|c}
\hline \multicolumn{1}{c|}{ Results } & No. cases \\
\hline Improved & $47(26)$ \\
Necessitated metal sound dilatation & $10(9)$ \\
Unfavorable & $7(1)$ \\
\hline \multicolumn{1}{c|}{ Total } & $64(36)$ \\
\hline
\end{tabular}

( ): Combined with TUR-P \&/or TUR-Bn 
自覚症状はやや軽減するも尿道造影上特に変化がみら れていない。これらはいずれも瘢痕のため充分尿道の 拡張が得られなかった症例であった。全症例とも術後 増悪した症例はなく，重篤な合併症も認められなかっ た。

\section{考 案}

内尿道切開術は現在でも MaisonneuveやOtis urethrotome が使用されているが112)，いずれも操作が 盲目的なのが欠点である。近年内視鏡の発達に伴い Dettmar's optical urethrotome が開発され，本邦でも

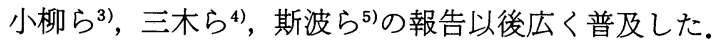

諸家の報告6)7 によれば治療成績は70９0\%の良好 な成功率で，われわれの成功率もほぼ同等であった。 また重篤な合併症も少なく優れた治療法と言える。

適応について, Gray and Biorn ${ }^{8}$ は, (1)頻回 $(1 \sim 2$ カ月に 1 回) の払張を要するもの，(2)瘦孔や喤室を伴 い拡張に麻酔を必要とするようなひどい狭窄，(3)ブ ジーによる拡張が不可能なもの，をあげている。われ われも当初上記の適応に従い手術を行なっていたが， 本術式の安全性から考学てブジーより優先させてもよ いのではないかと考光ている。一方，外傷性尿道狭窄 は洀痕化が強く，充分な尿道の拡大が得られないこと が多く，洀痕部の切除が必要である4)。また骨盤骨折を 伴う場合には尿道の偏位がみられることがあり, 適応 が困難である，禁忌としては急性炎症の存在，出血傾 向, 尿道癌などがある ${ }^{9}$.

手術手技に関しては, 陰茎海綿体中隔の存在する 12 時方向を切開するのが安全である ${ }^{4)}$. 充分な尿道の拡 張が得られない場合には 3 時, 9 時, 6 時方向の切開 を適宜追加する，切開の深さも重要で, 線維化した組 織を越えて健康な組織をで充分切開する ${ }^{10)}$. 膜様部尿 道の切開に際しては尿道括約筋の損傷に注意が必要で あるが，1 カ所のみであれば術後の尿失禁はない(4)10) と言われている。われわれも術後尿失禁の症例は経験 していない，むしろ注意深くなりすぎて, 切開が不充 分にならないことが大切である。

麻醉は TUR-P に準じ, 腰麻または硬膜外麻酔が一 般的であるが，キシロカインゼリーによる尿道粘膜麻 酔での報告11) ある。われわれも尿道粘膜麻酔で行 なった症例を 1 例経験したが，狭窄の程度が軽い症例 では充分可能と思われる。

カテーテルのサイズと留置期間についてはサイズが 大きすぎる場合または留置期間が長くなるほど再発の 可能性が高くなるため, 20 22Fr. のバルーンカテー
テルを $3 \sim 7$ 日間留置するのが一般的である ${ }^{12)}$.

効果判定には自覚症状, 金属ブジー，尿道造影括よ び尿流量測定により行なわれる，尿流量測定は侵襲が 少なく定量的に行なえるため, 効果判定の主流になる ものと考光られる ${ }^{12)}$. 術後経過観察の期間については 一定した基準がなく，また再発の頻度についても不明 な点が多く今後検討を要する問題である，TUR-Pま たはTUR-Bnを併せて行なった症例は自覚症状拈よ び尿流量測定では効果判定が困難なため, 金属ブジー および尿道造影が必要である。しかし術後の経過観察 に扔いては有用である。

TUR-P または TUR-Bnを併せて行なら場合, 最初 に直視下尿道切開術を行なって拈くと TUR の操作が スムーズに行なえる。岩田ら $\left.{ }^{13}\right)$ は Prostatic Age にお ける球部尿道狭窄の意義として経尿道手術時に損傷 し, 術後さらに高度な狭窄を生じる原因となりらると 述べている，この様な症例に対しては積極的に直視下 内尿道切開術を試みるべきであろう。

以上述べてきたごとく直視下内尿道切開術は，その 安全性, 確実性に加兄て, 内視鏡操作に習熟した泌尿 器科医にとっては手技的にも容易であるため, 今後尿 道狭窄治療の主流になると思われる。

\section{結語}

尿道狭窄を有する64例の患者に対し直視下内尿道切 開術を施行し以下の結果を得た。

1. 治療成績は57例 (89.5\%) に改善が得られた。術 後増悪した症例はなく, 重篤な合併症も認められな かった。

2. 直視下内尿道切開術は手技が簡単で, 安全かつ治 療成績の優れた方法である.

3. 今後, 尿道狭窄治療の主流になるものと思われ る.

本論文の要旨は第50回日本泌尿器科学会東部総会に扔い て発表した。

1）森永 修, 早石哲朗, 荒木 徹, 松村陽右：尿道狭 窄に対する内尿道切開術の経験。臨泌，32，1055 $-1059,1978$.

2）八木拡朗, 平田 弘：尿道狭窄に対する内尿道切 開術。西日泌尿，47，65-68，1976.

3）小柳知彦, 寺島光行, 过一郎：尿道狭窄治療の新 術式. 臨泌，31，65-71，1977.

4）三木 誠, 町田豊平, 新井由和, 小野寺昭一：直視 下内尿道切開術の経験。日泌尿，69，465-471, 1978.

5）斯波光生, 大橋伸生, 稲田文衛, 有馬 滋：尿道狭 
窄に対する経尿道的直視下手術の経験. 泌尿紀要, 24, 481-485, 1978.

6) Sackoff, E.J. and Kerr, W.S.: Direct vision cold knife urethrotomy. J. Urol., 123, 592-496, 1980.

7) Walther, P.C., Parsons, C.L. and Schmidt, J.D. : Direct vision internal urethrotomy in the management of urethral strictures. J. Urol., 123, 497-499, 1980.

8) Gray, C.P. and Biorn, C.L.: Internal urethrotomy: Its use in the treatment of urethral strictures of the male patient. J. Urol., 97, 713-715, 1967.

9) Kinder, P.W. and Rous, S.N.: The treatment of urethral stricture disease by internal ureth- rotomy : A clinical review. J. Urol., 121, 45-46, 1979.

10) Wolf, J.A. Jr. : Super otis urehrotomy. J. Urol., 97, 713-715, 1967.

11）李 漢栄, 沢村正之, 門脇和臣 : 尿道粘膜麻酔下に 内視鏡的内尿道切開術を施行した 1 例. 泌尿紀要, 32, 609-610, 1986.

12) 森岡政明, 小浜吉照, 渡辺裕修, 戦 泰和, 山下元 幸, 杉田 治, 小倉朱生, 義本志雄, 松本 茂, 大 橋洋三, 亀井義広, 藤田幸利: 直視下内尿道切開術 の経験. 西日泌尿，48，1503-1507，1986.

13）岩田英信, 大岡啓二, 岡本正紀, 森田 勝, 越知憲 二, 竹内正文, 別宮 徹：Prostatic Age における 球部尿道狭窄の意義。西日泌尿, 46, 220, 1984.

(1987年 2 月 9 日受理) 